\title{
Correction to: A randomized, multicentre, open-label phase II proof-of-concept trial investigating the clinical efficacy and safety of the addition of convalescent plasma to the standard of care in patients hospitalized with COVID-19: the Donated Antibodies Working against nCoV (DAWn- Plasma) trial
}

Timothy Devos ${ }^{1,2^{*}+}$, Tatjana Geukens ${ }^{1,2 \dagger}$, Alexander Schauwvlieghe ${ }^{3 \dagger}$, Kevin K. Ariën ${ }^{4}$, Cyril Barbezange ${ }^{5}$, Myriam Cleeren ${ }^{1}$, Veerle Compernolle ${ }^{6}$, Nicolas Dauby ${ }^{7}$, Daniël Desmecht ${ }^{8}$, David Grimaldi ${ }^{9}$, Bart N. Lambrecht ${ }^{3}$, Anne Luyten ${ }^{10}$, Piet Maes ${ }^{11}$, Michel Moutschen ${ }^{8}$, Marta Romano ${ }^{5}$, Lucie Seyler ${ }^{12}$, Michel Toungouz Nevessignsky ${ }^{13}$, Katleen Vandenberghe ${ }^{10}$, Johan van Griensven ${ }^{4}$, Geert Verbeke ${ }^{14}$, Erika Vlieghe ${ }^{15}$, Jean Cyr Yombi ${ }^{16}$, Laurens Liesenborghs ${ }^{11}$, Peter Verhamme ${ }^{1}$ and Geert Meyfroidt ${ }^{1}$

Correction to: Trials 21, 981 (2020) https://doi.org/10.1186/s13063-020-04876-0

Following publication of the original article [1], we were notified of a typing mistake in one of the author names.

Originally published name: Alexander Schauvlieghe.

Corrected name: Alexander Schauwvlieghe.

The original article has been corrected.

\section{Author details}

${ }^{1}$ University Hospitals Leuven (UZ Leuven), Leuven, Belgium. ${ }^{2}$ Catholic University of Leuven (KU Leuven), Leuven, Belgium. ${ }^{3}$ Universitair Ziekenhuis Gent, Ghent, Belgium. Instituut voor Tropische Geneeskunde, Antwerp,

The original article can be found online at https://doi.org/10.1186/s13063020-04876-0

* Correspondence: timothy.devos@uzleuven.be

${ }^{\dagger}$ Timothy Devos, Tatjana Geukens and Alexander Schauwvlieghe are co-first authors.

${ }^{1}$ University Hospitals Leuven (UZ Leuven), Leuven, Belgium

${ }^{2}$ Catholic University of Leuven (KU Leuven), Leuven, Belgium

Full list of author information is available at the end of the article
Belgium. ${ }^{5}$ Sciensano, Elsene, Belgium. ${ }^{6}$ Rode Kruis Vlaanderen, Mechelen, Belgium. ${ }^{7}$ Universite Libre de Bruxelles Institut d 'Immunologie Medicale, Bruxelles, Belgium. ${ }^{8}$ Universite de Liege, Liege, Belgium. ${ }^{9}$ Universite Libre de Bruxelles, Bruxelles, Belgium. ${ }^{10}$ Leuven Coordinating Centre, Leuven, Belgium. ${ }^{11}$ Katholieke Universiteit Leuven Rega Institute for Medical Research, Leuven, Belgium. ${ }^{12}$ Universitair Ziekenhuis Brussel, Bruxelles, Belgium. ${ }^{13}$ Croix Rouge de Belgique, Bruxelles, Belgium. ${ }^{14}$ Interuniversity Institute for Biostatistics and statistical Bioinformatics, Leuven, Belgium. ${ }^{15}$ Universitair Ziekenhuis Antwerpen, Antwerpen, Belgium. ${ }^{16}$ Cliniques Universitaires Saint-Luc, Sint-Lambrechts-Woluwe, Belgium.

Published online: 14 December 2020

\section{Reference}

Devos, et al. A randomized, multicentre, open-label phase II proof-ofconcept trial investigating the clinical efficacy and safety of the addition of convalescent plasma to the standard of care in patients hospitalized with COVID-19: the Donated Antibodies Working against nCoV (DAWn-Plasma) trial. Trials. 2020;21:981. https://doi.org/10.1186/s13063-020-04876-0.

C C The Author(s). 2020 Open Access This article is licensed under a Creative Commons Attribution 4.0 International License, which permits use, sharing, adaptation, distribution and reproduction in any medium or format, as long as you give appropriate credit to the original author(s) and the source, provide a link to the Creative Commons licence, and indicate if changes were made. The images or other third party material in this article are included in the article's Creative Commons licence, unless indicated otherwise in a credit line to the material. If material is not included in the article's Creative Commons licence and your intended use is not permitted by statutory regulation or exceeds the permitted use, you will need to obtain permission directly from the copyright holder. To view a copy of this licence, visit http://creativecommons.org/licenses/by/4.0/ The Creative Commons Public Domain Dedication waiver (http://creativecommons.org/publicdomain/zero/1.0/) applies to the data made available in this article, unless otherwise stated in a credit line to the data. 